\title{
Bioconversion of norethisterone, a progesterone receptor agonist into estrogen receptor agonists in osteoblastic cells
}

\author{
Ana E Lemus ${ }^{1,2}$, Juana Enríquez ${ }^{2}$, Ángeles Hernández ${ }^{1}$, René Santillán ${ }^{3}$ and Gregorio Pérez-Palacios ${ }^{3}$ \\ ${ }^{1}$ Department of Reproductive Biology, Universidad Autónoma Metropolitana Iztapalapa, Mexico City P.C. 09340, Mexico \\ ${ }^{2}$ Department of Reproductive Biology, Instituto Nacional de Ciencias Médicas y Nutrición S. Zubirán, Mexico City P.C. 14000, Mexico \\ ${ }^{3}$ National Institute of Perinatology and School of Medicine, Universidad Nacional Autónoma de México, Mexico City P.C. 11000, Mexico \\ (Correspondence should be addressed to A E Lemus; Email: anaelenalemus@prodigy.net.mx)
}

\begin{abstract}
A number of clinical studies have demonstrated that norethisterone (NET), a potent synthetic progestin, restores postmenopausal bone loss, although its mode of action on bone cells is not fully understood, while the effect of naturally occurring progesterone in bone has remained controversial. A recent report claims that the potent effects of NET on osteoblastic cell proliferation and differentiation, mimicking the action of estrogens, are mediated by non-phenolic NET derivatives. To determine whether osteoblasts possess the enzymes required to bioconvert a progesterone receptor (PR) agonist into A-ring reduced metabolites with affinity to bind estrogen receptor (ER), we studied the in vitro metabolism of $\left[{ }^{3} \mathrm{H}\right]$-labeled NET in cultured neonatal rat osteoblasts and the interaction of its metabolic conversion products with cytosolic -osteoblast ER, employing a competition analysis. Results indicated that NET was extensively bioconverted
\end{abstract}

$(36 \cdot 4 \%)$ to $5 \alpha$-reduced metabolites, including $5 \alpha$-dihydro NET, $3 \alpha, 5 \alpha$-tetrahydro NET $(3 \alpha, 5 \alpha-N E T)$ and $3 \beta, 5 \alpha-$ tetrahydro NET $(3 \beta, 5 \alpha-\mathrm{NET})$, demonstrating the activities of $5 \alpha$-steroid reductase and two enzymes of the aldo-keto reductases family. Expression of Srd5a1 in neonatal osteoblast was well demonstrated, whereas $\operatorname{Srd5a2}$ expression was not detected. The most striking finding was that $3 \beta, 5 \alpha-\mathrm{NET}$ and $3 \alpha, 5 \alpha-\mathrm{NET}$ were efficient competitors of $\left[{ }^{3} \mathrm{H}\right]$-estradiol for osteoblast ER binding sites, exhibiting affinities similar to that of estradiol. The results support the concept that the interplay of $5 \alpha$-steroid reductase and aldo-keto reductases in osteoblastic cells, acting as an intracrine modulator system is capable to bioconvert a PR agonist into ER agonists, offering an explanation of the molecular mechanisms NET uses to enhance osteoblastic cell activities.

Journal of Endocrinology (2009) 200, 199-206

\section{Introduction}

A number of clinical trials have demonstrated that administration of norethisterone (NET), a synthetic 19-nor progestin, to postmenopausal women prevents bone mineral loss and reduces bone resorption (Abdalla et al. 1985, Horowitz et al. 1993) and also prevents bone loss in young women treated with LH-releasing agonists (Riis et al. 1990). The mechanisms of estrogen-like bone actions of NET are not fully understood, particularly since this steroid molecule neither interacts with estrogen receptors (ER; Chávez et al. 1985) nor undergoes enzyme-mediated aromatization (Gual et al. 1962). Interestingly, a study conducted in postmenopausal women and castrated patients with complete androgen resistance, strongly suggested that the antigonadotropic effect of NET is mediated through ER (Pérez-Palacios et al. 1981).

Recently, evidence has been presented indicating that two reduced derivatives of NET, $3 \beta, 5 \alpha$ tetrahydro-NET $(3 \beta, 5 \alpha-$ NET) and $3 \alpha, 5 \alpha$ tetrahydro-NET $(3 \alpha, 5 \alpha-\mathrm{NET})$, induced significant effects on rat osteoblast proliferation, differentiation, and mineralization processes, mimicking the effects of estradiol $\left(\mathrm{E}_{2}\right)$. The osteoblast proliferation induced by NET reduced derivatives was suppressed by the addition of ICI 182 780 , a potent steroidal antiestrogen, indicating that this effect is mediated by ER. The study also provides evidence that high concentrations of unmodified NET exhibited estrogenic potency in osteoblastic cells, though these effects were suppressed by finasteride, a selective steroid $5 \alpha$-reductase inhibitor (Enríquez et al. 2007).

Androgen metabolizing enzymes have been demonstrated in bone cells; thus, several reports have documented the activities and gene expression of $5 \alpha$-reductase 1 and 2 in human osteoblastic cells Shimodaira et al. (1996), Issa et al. (2002) and Vittek et al. (1974), using testosterone as a substrate, demonstrated the activity of $3 \alpha$-hydroxysteroid dehydrogenase $(3 \alpha-\mathrm{HSD})$ in rat mandibular bone. Previous studies from our laboratory have demonstrated that synthetic 19-nor progestins are extensively metabolized in target organs 
to A-ring reduced tetrahydro derivatives (Larrea et al. 1987, Lemus et al. 1992, 2001), which exert estrogen-like effects (Vilchis et al. 1986, Moralí et al. 1990, Lemus et al. 2000, Santillán et al. 2001).

To assess if NET is bioconverted to non-phenolic reduced metabolites with intrinsic estrogenic potency in osteoblasts, we studied the metabolism of $\left[{ }^{3} \mathrm{H}\right]$-labeled NET in rat cultured osteoblastic cells and the interaction of NET and its $5 \alpha$-reduced metabolites with the osteoblast intracellular ER. The identification of NET metabolites was established by a reverse isotope dilution technique, while their interaction with ER was assessed by competition analysis using $\left[{ }^{3} \mathrm{H}\right]-\mathrm{E}_{2}$ as the radioligand. In addition, the gene expression of $5 \alpha$-steroid reductase type $1(\operatorname{Srd} 5 a 1)$ and type $2(\operatorname{Srd} 5 a 2)$ was studied using RT-PCR.

\section{Materials and Methods}

\section{Steroids and chemicals}

$\left[6,7-{ }^{3} \mathrm{H}\right]$ NET $\left(\left[{ }^{3} \mathrm{H}\right]-\mathrm{NET}\right)$, specific activity (sp. act.) $55 \mathrm{Ci} / \mathrm{mmol}$ was kindly provided by Schering (Berlin, Germany), $\left[2,4,6,7,16,17-{ }^{3} \mathrm{H}\right]$ estradiol $\left(\left[{ }^{3} \mathrm{H}\right]-\mathrm{E}_{2}\right)$, sp. act. $157 \mathrm{Ci} / \mathrm{mmol}$ was purchased from Amersham International and their radiochemical purity was established by thin-layer chromatographic behavior. Authentic NET was kindly provided by Schering Mexicana, S.A. de C.V. (Mexico City, Mexico). Synthesis of $5 \alpha$-dihydronorethisterone $(5 \alpha-$ NET), $3 \alpha, 5 \alpha-\mathrm{NET}$, and $3 \beta, 5 \alpha-\mathrm{NET}$ was previously reported (Chávez et al. 1985). The chemical purity of NET and its reduced derivatives was assessed by their melting points, HPLC behavior, infrared absorption, and $\mathrm{H}$-nuclear magnetic resonance. The physical and spectroscopic constants of the A-ring reduced derivatives of NET have been previously described (Chávez et al. 1985). Other non-radioactive steroids were supplied by Sigma Chemical Co. Fetal bovine serum (FBS) was purchased from Hyclone Laboratories Inc., and phenol red-free DMEM from Life Technologies. Reverse transcriptase RT-PCR kit and TRIzol reagent were purchased from Invitrogen. TaqMan Universal PCR Master Mix and TaqMan probes and primers were obtained from Applied Biosystems (Foster City, CA, USA). Reagents and solvents used were of analytical grade.

\section{Animals}

Female neonatal Wistar rats used in this study were obtained from the School of Medicine, Universidad Nacional Autónoma de México (UNAM). Animals were killed by decapitation and calvariae were immediately removed. All procedures were performed in accordance with the Guidelines on the Handling and Training of Laboratory Animals, published by the Universities Federation for Animal Welfare and approved by the Research Ethics Board of the Universidad Autónoma Metropolitana (UAM).
Isolation and culture of rat osteoblastic cells

Osteoblastic calvarial cells from 1 day old rats were used throughout the study. Calvariae were carefully dissected, cleaned from connective tissue, periosteum and cartilaginous part, and sequentially digested for $60 \mathrm{~min}$ with $0 \cdot 3 \%$ type II collagenase (Robey 1995). Cells obtained in the first treatment were discarded, while cells isolated from the subsequent three digestions were pooled, plated, and cultured overnight in DMEM supplemented with $10 \%$ FBS and $100 \mu \mathrm{M}$ non-essential amino acids and an antibioticsantimycotic solution $(100 \mathrm{U} / \mathrm{ml}$ penicillin, $100 \mu \mathrm{g} / \mathrm{ml}$ streptomycin and $250 \mathrm{ng} / \mathrm{ml}$ amphotericin-B; Gibco BRL) and $50 \mu \mathrm{g} / \mathrm{ml}$ ascorbic acid, at $37^{\circ} \mathrm{C}$ in a humidified atmosphere of $5 \% \mathrm{CO}_{2}$ in air.

Assessment of the phenotype of cultured rat calvarial cells was done by determining the presence of alkaline phosphatase activity and osteocalcin, according to the methods described by Kaplow (1955) and Arzate et al. (1998) respectively. The results revealed the presence of these two bone-related proteins in more than $95 \%$ of the calvarial cells, thus demonstrating the distinctive features of the osteoblast phenotype. At confluence, primary rat osteoblasts were detached with $1 \mathrm{mM}$ EDTA/0.25\% trypsin solution, counted and submitted to metabolism and ER competition studies.

\section{Norethisterone metabolism}

To assess the bioconversion of NET to its A-ring reduced derivatives, the metabolism of $\left[{ }^{3} \mathrm{H}\right]-\mathrm{NET}$ in cultured osteoblastic cells was studied. Osteoblasts were plated at a density of $2 \times 10^{6} /$ Petri dish and incubated for $24 \mathrm{~h}$ in culture medium (DMEM at $\mathrm{pH} 7 \cdot 4$, containing $10 \%$ charcoaldextran treated (stripped) FBS, non-essential amino acids, antibiotics-antimycotic solution) and $50 \mu \mathrm{g} / \mathrm{ml}$ ascorbic acid, at $37^{\circ} \mathrm{C}$ in a humidified atmosphere of $5 \% \mathrm{CO}_{2}$ in air. The culture medium was removed and replaced by fresh medium containing $2 \mu \mathrm{M}\left[{ }^{3} \mathrm{H}\right]-\mathrm{NET}$ and incubated at $37^{\circ} \mathrm{C}$, for 6,24 , and $48 \mathrm{~h}$, under $5 \% \mathrm{CO}_{2}$-air atmosphere. The optimal concentration of substrate $\left(\left[{ }^{3} \mathrm{H}\right]-\mathrm{NET}\right)$ employed in these experiments, was derived from previous studies aimed to characterize the kinetic constant $\left(K_{\mathrm{M}}\right)$ at equilibrium of $5 \alpha-$ steroid reductase in different tissues, using testosterone and gestodene, other synthetic 19-norprogestin as substrates (Lemus et al. 2001). Final incubation volume was $3 \mathrm{ml}$. Cell-free and boiled inactivated cell incubations carried out under identical experimental conditions were used as negative controls. Protein content was determined by the Bradford's dye-binding method (1976), using BSA as standard. Additional experiments with $\left[{ }^{3} \mathrm{H}\right]$-NET were conducted in the presence or absence of $1 \mathrm{mM}$ finasteride (Merck Sharp \& Domhe, Mexico City, Mexico). At the end of the incubation period, the reaction was stopped by the addition of ethyl acetate and radiolabeled steroids were extracted $(4 \times)$ using three volumes of water saturated ethyl acetate. The organic extracts were partitioned between petroleum ether and 10\% 
aqueous methanol and $5 \mu \mathrm{g}$ each of the following steroid carriers were added to the methanolic extracts: NET, $5 \alpha-$ NET, $3 \alpha, 5 \alpha-N E T$, and $3 \beta, 5 \alpha-N E T$. The identification of NET metabolites was established by a reverse-isotope dilution technique, including identical behavior of the steroid carriers in two different thin layer chromatographic systems (chloroform-acetone 9:1 and benzene-ethyl acetate 2:1). Radioactivity was determined in a Packard Tri-Carb liquid scintillation spectrometer model $1900 \mathrm{TR}$, using toluene containing $4 \mathrm{~g} / \mathrm{lPPO}$ and $100 \mathrm{mg} / \mathrm{l}$ dimethyl POPOP as the counting solution. Counting efficiency for $\left[{ }^{3} \mathrm{H}\right]$ was $65 \%$ and quenching was corrected in all samples by external standardization. Non-radioactive steroid carriers were detected on chromatograms using the $p$-anisaldehyde-sulphuric/acetic acids reagent. The formation rates of the metabolic conversion products of NET are expressed as $\mathrm{pmol} / \mathrm{mg}$ of protein.

\section{Isolation of total RNA and real-time PCR}

The expression of Srd5a1 and Srd5a2 in osteoblastic cells was detected by RT-PCR. Total RNA from the cells $\left(6 \times 10^{6}\right)$ was extracted using TRIzol reagent and an aliquot $(3 \mu \mathrm{g})$ from each sample was subjected to reverse transcription using a superscript first-strand cDNA synthesis kit, according to the manufacturer's protocol. Samples were subjected to quantitative amplification using the TaqMan probe and primers sets of Srd5a1 (Rn00567064-_ml) and Srd5a2 (Rn00575595_ml). PCR amplification was carried out in triplicate for each sample and performed in a total volume of $10 \mu \mathrm{l}$ containing $75 \mathrm{ng}$ of cDNA, $900 \mathrm{nM}$ of each primer, $250 \mathrm{nM}$ of the respective probe, and $6 \mu \mathrm{l}$ of TaqMan Universal PCR Master Mix. All PCRs were done including one initial step of DNA polymerase activation for $10 \mathrm{~min}$ at $95^{\circ} \mathrm{C}$ and then 40 cycles $\left(15 \mathrm{~s}\right.$ at $95^{\circ} \mathrm{C}$ and $1 \mathrm{~min}$ at $\left.60^{\circ} \mathrm{C}\right)$. Gene expression was normalized with the expression of the housekeeping $\beta$-actin gene (mRNA enzyme/mRNA $\beta$-actin). mRNA rat anterior ventral prostate was used as a positive control and RNAs without RT were used as a negative control. Results are given as relative mRNA expression.

\section{Estrogen receptor binding studies}

Cytosol preparation Osteoblastic cells were plated in culture medium at a density of $5 \times 10^{6}$ cells/flask and incubated for 2 weeks at $37^{\circ} \mathrm{C}$, in a $5 \% \mathrm{CO}_{2}$-air atmosphere, with medium replacement every other day. At the end of the incubation period, the culture medium was removed, replaced by $5 \%$ stripped FBS medium and incubated for an additional $3 \mathrm{~h}$. Cells were detached using $1 \mathrm{mM}$ EDTA/0 $25 \%$ trypsin solution, harvested and centrifuged at $286 \mathrm{~g}$ for $5 \mathrm{~min}$. The cellular pellet was resuspended in TEDLM buffer $(20 \mathrm{mM}$ Tris- $\mathrm{HCl}, \mathrm{pH} 7.4$ at $4{ }^{\circ} \mathrm{C}, 1.5 \mathrm{mM}$ EDTA, $0.25 \mathrm{mM}$ dithiotreitol, $10 \mu \mathrm{g} / \mathrm{ml}$ leupeptine, and $10 \mathrm{mM}$ sodium molibdate), the number of cells determined $\left(1 \times 10^{8}\right)$ and submitted to sonication. Cytosolic fraction was obtained by centrifugation at $160000 \mathrm{~g}$ for $1 \mathrm{~h}$ at $4{ }^{\circ} \mathrm{C}$ in an SW 50.1 rotor
(Beckman Instruments, Palo Alto, CA, USA) and protein content was determined.

Binding assays Equilibrium parameters of the reaction between $\left[{ }^{3} \mathrm{H}\right]-\mathrm{E}_{2}$ and cytosol limited-capacity binding sites were studied by incubation of cytosol aliquots $(400 \mu \mathrm{g}$ protein/ml) for $18 \mathrm{~h}$ at $4{ }^{\circ} \mathrm{C}$, with $0 \cdot 25 \mathrm{nM}\left[{ }^{3} \mathrm{H}\right]-\mathrm{E}_{2}$ and increasing concentrations $(0.5-5.0 \mathrm{nM})$ of non-radioactive $E_{2}$. Bound and free $E_{2}$ were separated by the addition of $800 \mu \mathrm{l}$ of a dextran-coated charcoal suspension $(250 \mathrm{mg}$ Norit-A and $25 \mathrm{mg}$ dextran T-70) in TEDLM buffer and incubated for $10 \mathrm{~min}$ at $4{ }^{\circ} \mathrm{C}$ with continuous shaking. Following centrifugation at $800 \mathrm{~g}$ at $4{ }^{\circ} \mathrm{C}$, for $10 \mathrm{~min}$, the radioactive content of the supernatant was determined in $200 \mu \mathrm{l}$ aliquots, using Packard Insta-Gel PlusTM as the counting solution. The equilibrium $K_{\mathrm{d}}$ and the number of binding sites (NBS) were determined by the method of Scatchard (1949).

Competition studies Stereospecificity of the binding of NET, $5 \alpha-\mathrm{NET}, 3 \alpha, 5 \alpha-\mathrm{NET}$, and $3 \beta, 5 \alpha-\mathrm{NET}$ to ER, was assessed by competition analysis (Lemus et al. 2000), using dexamethasone as control. Cytosol aliquots $(400 \mu \mathrm{g}$ protein/ml) were incubated with $0 \cdot 25 \mathrm{nM}\left[{ }^{3} \mathrm{H}\right]-\mathrm{E}_{2}$ at $4{ }^{\circ} \mathrm{C}$ for $18 \mathrm{~h}$, in the absence or presence of increasing concentrations $(0 \cdot 25,0 \cdot 50,0 \cdot 75,1 \cdot 0 \mathrm{nM})$ of radioinert $\mathrm{E}_{2}$ and NET and its $5 \alpha$-reduced derivatives. The relative binding affinities (RBA) of steroid competitors to cytosol ER, were evaluated by their capability to displace bound $\left[{ }^{3} \mathrm{H}\right]-\mathrm{E}_{2}$ from the ER binding sites. The results are expressed as the inhibition constants $\left(K_{\mathrm{i}}\right)$ and RBA of steroid competitors, as described by Cheng \& Prusoff (1973) and Reel et al. (1979) respectively.

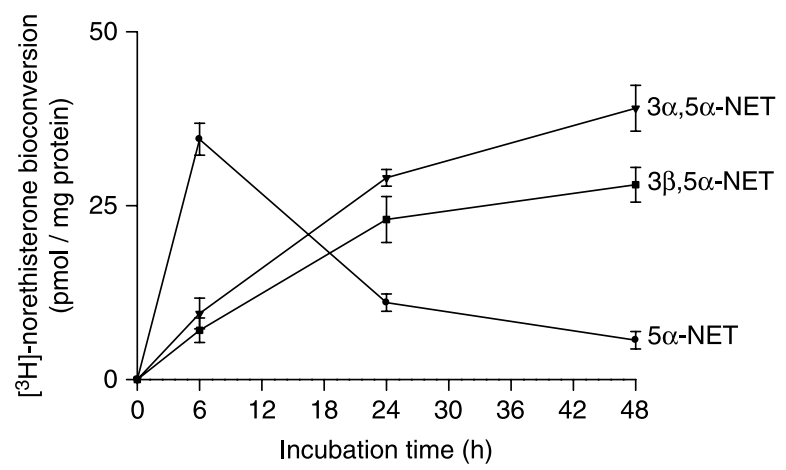

Figure 1 Formation of $5 \alpha$-reduced norethisterone (NET) metabolites in cultured neonatal rat osteoblastic cells. Incubations were carried out using $2 \mu \mathrm{M}\left[{ }^{3} \mathrm{H}\right]-\mathrm{NET}$ at different time periods. An early bioconversion of NET to $5 \alpha$-dihydro NET ( $5 \alpha$-NET) with a subsequent decline and a concomitant increase on the formation of $3 \alpha, 5 \alpha$-tetrahydro NET $(3 \alpha, 5 \alpha$-NET) and $3 \beta, 5 \alpha$-tetrahydro NET $(3 \beta, 5 \alpha-\mathrm{NET})$ was noticed. At 48 -h incubation, $36 \cdot 4 \%$ of the $\left[{ }^{3} \mathrm{H}\right]-$ substrate was bioconverted to A-ring reduced NET metabolites. Each point represents the mean \pm s.D. in three experiments in triplicate. 


\section{Results}

Norethisterone metabolism in osteoblastic cells

After partition of the osteoblastic cells organic extracts, $96 \%$ of the incubated radioactive material was recovered in the methanolic fraction. When aliquots of methanolic extracts from $\left[{ }^{3} \mathrm{H}\right]$-NET incubations were submitted to thin-layer chromatography, four radioactive zones were detected: Zone $1\left(R_{\mathrm{F}}=0 \cdot 61\right)$, had a chromatographic behavior identical to that of the $5 \alpha$-NET carrier. Zone $2\left(R_{\mathrm{F}}=0 \cdot 46\right)$ was identified as unchanged $\left[{ }^{3} \mathrm{H}\right]-\mathrm{NET}$, while Zone $3\left(R_{\mathrm{F}}=0 \cdot 43\right)$, had a chromatographic behavior identical to that of the $3 \alpha, 5 \alpha-\mathrm{NET}$ carrier and Zone $4\left(R_{\mathrm{F}}=0.38\right)$ corresponded to $3 \beta, 5 \alpha-\mathrm{NET}$.

The results show that NET was extensively metabolized in rat osteoblasts to three A-ring reduced derivatives, $5 \alpha-\mathrm{NET}$, $3 \alpha, 5 \alpha-\mathrm{NET}$, and $3 \beta, 5 \alpha-\mathrm{NET}$, demonstrating the activities of $5 \alpha$-steroid reductase, $3 \alpha-\mathrm{HSD}$ and $3 \beta-\mathrm{HSD}$. Representative results of the formation rates of NET metabolites, as a function of time, are shown in Fig. 1. After 24 h, 27.5\% of the incubated $\left[{ }^{3} \mathrm{H}\right]-\mathrm{NET}$ was bioconverted to its reduced metabolites $(63.5 \pm 1.9 \mathrm{pmol} / \mathrm{mg}$ protein), while at $48 \mathrm{~h}$ the conversion rate increased to $36 \cdot 4 \%(72 \cdot 6 \pm 2 \cdot 2 \mathrm{pmol} / \mathrm{mg}$ protein). The major metabolic conversion products were $3 \alpha, 5 \alpha-\mathrm{NET}$ and $3 \beta, 5 \alpha-\mathrm{NET}$, presumably through a prior conversion of NET to $5 \alpha-\mathrm{NET}$. Indeed, the maximal accumulation of $5 \alpha-\mathrm{NET}$ occurred at $6 \mathrm{~h}$, with a subsequent

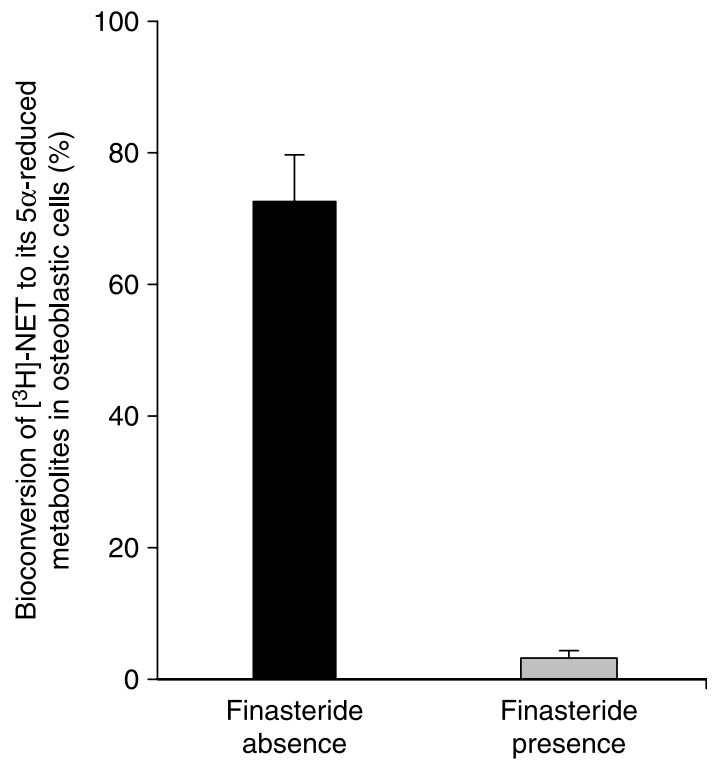

Figure 2 Effect of a $5 \alpha$-steroid reductase inhibitor on the metabolism of NET in cultured rat osteoblastic cells. Incubations of osteoblasts with $2 \mu \mathrm{M}\left[{ }^{3} \mathrm{H}\right]-\mathrm{NET}$ were carried out at $37^{\circ} \mathrm{C}$, $\mathrm{pH} 7 \cdot 4$ for $48 \mathrm{~h}$, in the absence or presence of $1 \mathrm{mM}$ finasteride. The presence of the $5 \alpha$-steroid reductase inhibitor resulted in a complete abolishment of bioconversion of NET to $5 \alpha$-dihydro NET, which precluded the formation of $3 \beta, 5 \alpha-N E T$ and $3 \alpha, 5 \alpha-N E T$. Data represents the mean \pm s.D. of three experiments in triplicate.
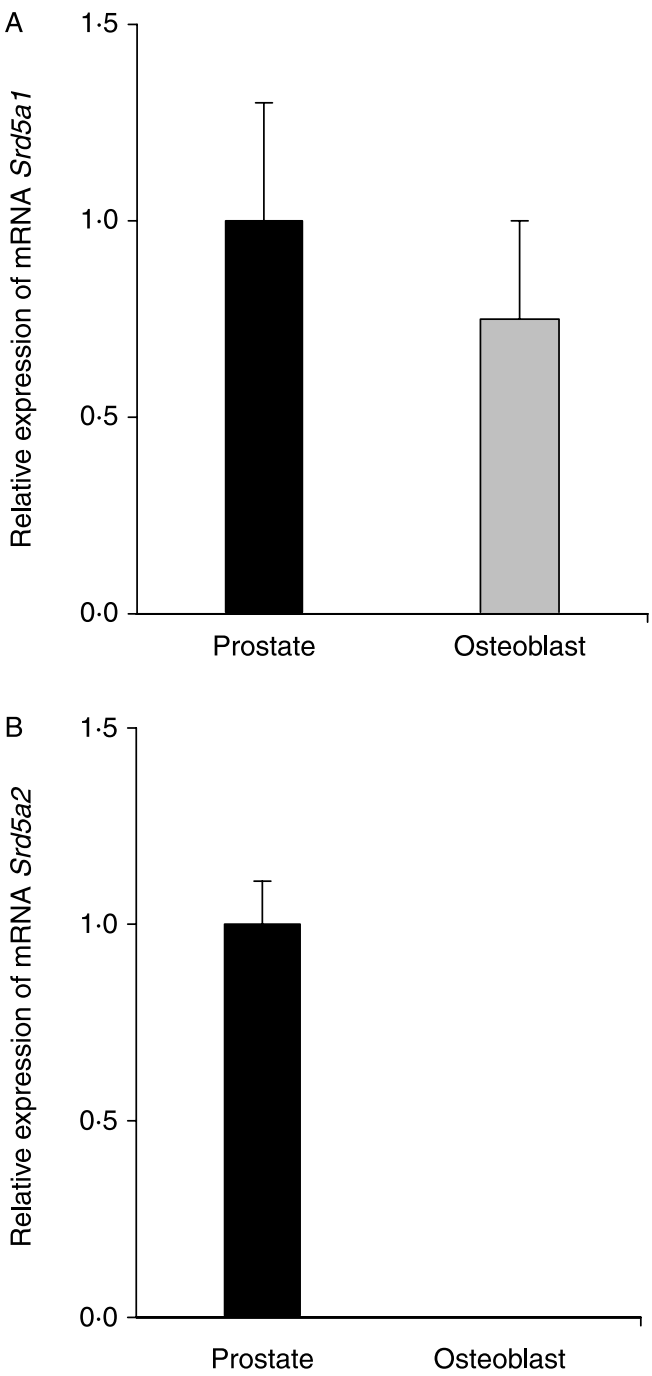

Figure $35 \alpha$-steroid reductase type 1 (Srd5a1) and type 2 (Srd5a2) mRNA expression levels in rat osteoblastic cells. Experiments were performed using real-time PCR. Total RNA was obtained from cultured neonatal rat osteoblasts and from rat anterior ventral prostate, used as experimental control. The expression of Srd5a1 was detectable in osteoblast at a similar level to that observed in control anterior ventral prostate (A). Gene expression of Srd5a2 in osteoblastic cells was not detectable (B), whereas gene expression of $5 \alpha$-steroid reductase type 2 in control rat ventral prostate was clearly detected.

decline and a concomitant increase on the formation of NET tetrahydro metabolites. Osteoblastic cells were incubated with $2 \mu \mathrm{M}\left[{ }^{3} \mathrm{H}\right]-\mathrm{NET}$ in the absence or presence of $1 \mathrm{mM}$ finasteride, a $5 \alpha$-steroid reductase inhibitor, at $37^{\circ} \mathrm{C}$, for $48 \mathrm{~h}$. As can be seen in Fig. 2, the presence of finasteride resulted in a complete inhibition of the formation of its corresponding $5 \alpha$-dihydro metabolite, which precluded the formation of NET-tetrahydro metabolites. Only unmodified radiolabeled NET was recovered from boiled inactivated cells and cell-free incubations, used as negative controls. 
Steroid $5 \alpha$-reductase genes expression

A number of experiments were performed to investigate the gene expression of type 1 and type 2 steroid $5 \alpha$-reductase in neonatal rat osteoblastic cells using RT-PCR. The Srd5a1 expression (Fig. 3A) was detected in osteoblastic cells, as well as in the anterior ventral prostate from rat adult males used as positive control. The expression level of Srd5a1 in the osteoblastic cells was similar to that of control anterior ventral prostate. Expression of Srd5a2 in osteoblastic cells was not detected, while Srd5a2 expression in anterior ventral prostate was clearly noticed, as it was expected. Results are shown in Fig. 3B.

\section{Estrogen receptor binding studies}

Saturation curve and Scatchard plot of $\left[{ }^{3} \mathrm{H}\right]-\mathrm{E}_{2}$ binding to cytosol preparations from rat osteoblastic cells are shown in Fig. 4. The $K_{\mathrm{d}}$ was $1.19 \times 10^{-9} \mathrm{M}$ and the number of ER binding sites was $0.39 \times 10^{-9} \mathrm{M}$. In addition to the highaffinity ER sites, a higher capacity specific binding site (type II) was noticed in osteoblasts at $E_{2}$ concentrations above $3 \mathrm{nM}$ (Fig. 4 inset).

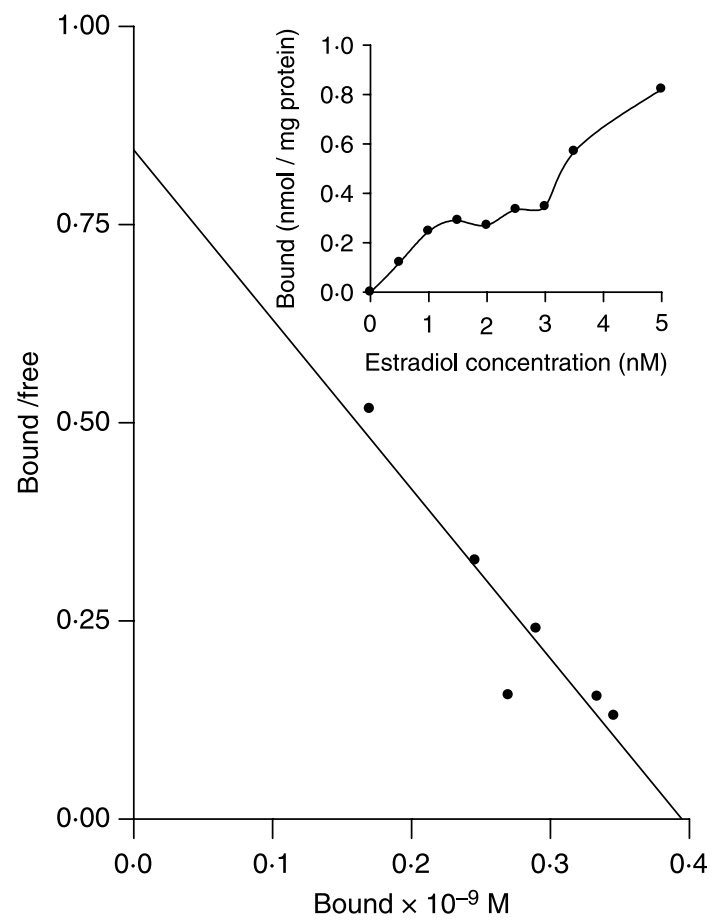

Figure 4 Representative Scatchard plot of the in vitro labeling of cytosol estrogen receptors (ER) of neonatal rat osteoblasts. Cytosol samples $(400 \mu \mathrm{g}$ protein $/ \mathrm{ml})$ were incubated with $\left.0 \cdot 25 \mathrm{nM} \mathrm{[}{ }^{3} \mathrm{H}\right]-$ estradiol $\left(E_{2}\right)$ in the presence of increasing concentrations of nonlabeled $\mathrm{E}_{2}(0 \cdot 5-5 \cdot 0 \mathrm{nM})$. The apparent $K_{\mathrm{d}}$ of osteoblasts ER was $1 \cdot 19 \times 10^{-9} \mathrm{M}$. The saturation curve shows a second, high-capacity $\mathrm{E}_{2}$ binding site (inset). The curve is representative of two experiments in triplicate. Cytosol preparation and incubation conditions are detailed in the text.
The competition of NET and its A-ring reduced metabolites for osteoblasts ER is depicted in Fig. 5. The addition of increasing concentrations of $E_{2}$, NET, $5 \alpha-N E T$, $3 \alpha, 5 \alpha-\mathrm{NET}, 3 \beta, 5 \alpha-\mathrm{NET}$, and dexamethasone induced different degrees of displacement of $\left[{ }^{3} \mathrm{H}\right]-\mathrm{E}_{2}$ from the osteoblasts cytosol ER. The most potent steroid competitors for ER binding sites were $\mathrm{E}_{2}, 3 \beta, 5 \alpha-\mathrm{NET}$, and $3 \alpha, 5 \alpha-\mathrm{NET}$, while unmodified NET and its $5 \alpha$-dihydro metabolite were unable to compete for ER, in a similar manner to that of dexamethasone, used as a negative control. The RBA and $K_{\mathrm{i}}$ of each steroid competitor are listed in Table 1.

\section{Discussion}

The results of this study clearly demonstrated that neonatal rat osteoblastic cells, efficiently biotransform the potent synthetic progestin NET to A-ring tetrahydro reduced metabolites, which possess the capability to bind with high affinity to osteoblasts ER. Indeed, rat osteoblasts incubated with radiolabeled NET exhibited a large formation of $3 \alpha, 5 \alpha-$ $\mathrm{NET}$, and $3 \beta, 5 \alpha-\mathrm{NET}$, indicating a great activity of $5 \alpha$-steroid reductase and two enzymes of the aldo-keto reductases family, $3 \alpha-\mathrm{HSD}$ and $3 \beta-\mathrm{HSD}$. The results of the metabolic study suggest that the formation of the tetrahydro reduced NET metabolites is preceded by the enzyme mediated $5 \alpha$-reduction of NET. Indeed, the early and high formation of $5 \alpha-\mathrm{NET}(6 \mathrm{~h})$ as an obligatory intermediary, was followed by a decline and a concomitant significant increase of $3 \alpha, 5 \alpha-\mathrm{NET}$ and $3 \beta, 5 \alpha-\mathrm{NET}$ formation (Fig. 1).

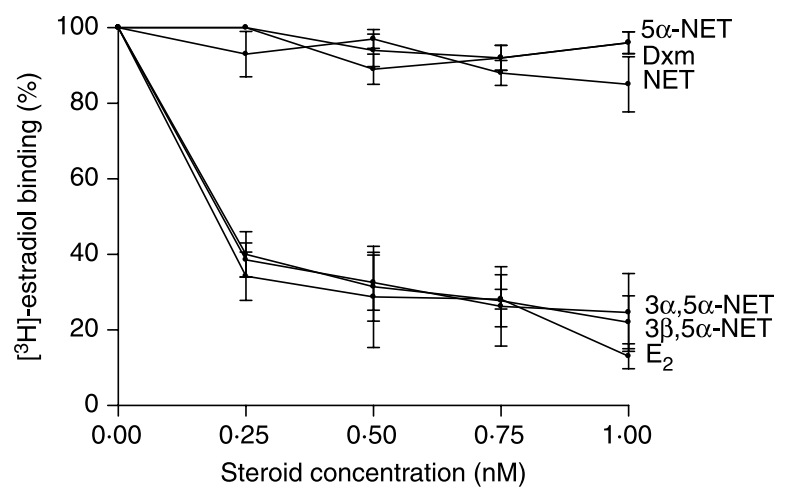

Figure 5 Interaction of estradiol $\left(E_{2}\right)$, norethisterone (NET) and its $5 \alpha$-reduced metabolites with cytosol estrogen receptors (ER) of neonatal rat osteoblasts. Cytosol samples $(400 \mu \mathrm{g}$ protein $/ \mathrm{ml})$ were incubated with $0 \cdot 25 \mathrm{nM}\left[{ }^{3} \mathrm{H}\right]-\mathrm{E}_{2}$, in the absence or presence of increasing concentrations of radioinert natural and synthetic steroids: $\mathrm{E}_{2}, \mathrm{NET}, 5 \alpha$-dihydro NET ( $5 \alpha$-NET), $3 \alpha, 5 \alpha$-tetrahydro NET $(3 \alpha, 5 \alpha-\mathrm{NET})$, and $3 \beta, 5 \alpha$-tetrahydro NET $(3 \beta, 5 \alpha-\mathrm{NET})$. Dexamethasone (Dxm) was used as experimental control. Binding of $\left[{ }^{3} \mathrm{H}\right]-\mathrm{E}_{2}$ in the absence of competitor was set at $100 \%$. 3 $3,5 \alpha-N E T, 3 \alpha, 5 \alpha-N E T$, and $E_{2}$ were the most effective competitors for ER binding sites. Unmodified NET, $5 \alpha-N E T$, and Dxm were completely ineffective. Each point represents the mean \pm s.D. of three experiments in triplicate. 
Table 1 Relative binding affinities (RBA) and inhibition constant $\left(K_{\mathrm{i}}\right)$ of natural and synthetic steroids for rat osteoblast cytosol estrogen binding sites, as assessed by competition analysis. $\left[{ }^{3} \mathrm{H}\right]$-Estradiol was used as radioligand and dexamethasone as the negative control

\begin{tabular}{|c|c|c|}
\hline & RBA $(\%)$ & $\boldsymbol{K}_{\mathbf{i}}(\mathrm{nM})$ \\
\hline \multicolumn{3}{|l|}{ Steroids } \\
\hline Estradiol & 100 & $0 \cdot 15$ \\
\hline $3 \beta, 5 \alpha-N E T$ & 95 & $0 \cdot 16$ \\
\hline $3 \alpha, 5 \alpha-\mathrm{NET}$ & 90 & $0 \cdot 17$ \\
\hline $5 \alpha-N E T$ & - & - \\
\hline Norethisterone & - & - \\
\hline Dexamethasone & - & - \\
\hline
\end{tabular}

The presence of finasteride in osteoblast incubations with NET induced a complete inhibition of $5 \alpha$-NET formation, indicating that $5 \alpha$-reduction of NET is an essential metabolic step for the formation of NET tetrahydro derivatives. Furthermore, these results demonstrated that $5 \alpha$-reduction (trans A/B ring junction) is required, as a prior step, in the intracrine sequence of events, leading to the formation of NET metabolites with ER agonistic potency in osteoblastic cells. The data indicate that $5 \alpha$-NET formation represents an essential metabolic step for the effects of NET on bone cells.

Furthermore, the expression of Srd5a1 in neonatal rat osteoblastic cells was clearly demonstrated while the expression of $\operatorname{Srd5a2}$ was not detected. The striking finding of selective expression of Srd5a1 in neonatal rat osteoblastic cells is in line with the reports of van der Eerden et al. (2004), who have demonstrated gene expression of the $5 \alpha$-steroid reductase type 1 in rat tibia metaphysis and Issa et al. (2002) who have demonstrated that gene expression of $5 \alpha$-steroid reductase type 1 is the predominant enzyme in human osteoblast-like cells.

The data confirm and extend the results of previous studies, which have demonstrated the bioconversion of 19-nor synthetic progestins to their A-ring reduced metabolites in other sex steroid hormone sensitive tissues (Larrea et al. 1987, Lemus et al. 1992, 2001). The results are also in line with the presence of androgen metabolizing enzymes reported in bone and bone cells (Vittek et al. 1974, Shimodaira et al. 1996, Issa et al. 2002). More recently, McCarthy et al. (2007) have demonstrated in fetal rat osteoblasts, the conversion of tibolone, a synthetic $7 \alpha$-methylated androgen receptor agonist, into its 3-hydroxylated metabolites, which are potent ER $\alpha$ agonists.

The most relevant finding of this study was that $3 \beta, 5 \alpha$ NET and $3 \alpha, 5 \alpha-N E T$, the major metabolic conversion products of NET in intact neonatal rat osteoblasts, were also the most efficient competitors for ER binding sites in cytosol preparations of the same rat osteoblasts, exhibiting relative binding affinities similar, almost identical, to that of naturally occurring $E_{2}$, while unmodified NET and $5 \alpha$-NET were ineffective competitors for the binding sites of ER, in a similar manner to that of dexamethasone used as a negative control. The results fit well with previous observations from our

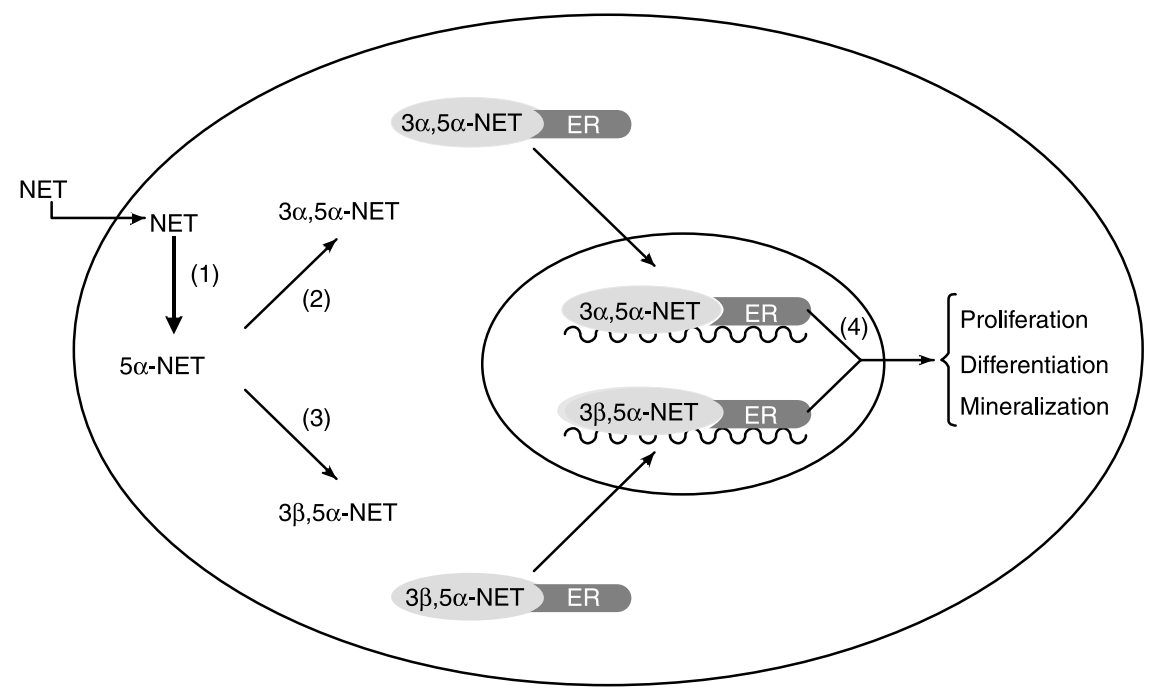

Figure 6 An intracrine model of the action of a 19-norprogestin in osteoblast. The bioconversion of norethisterone (NET) into two A-ring reduced metabolites $(3 \beta, 5 \alpha$-NET and $3 \alpha, 5 \alpha$-NET), which bind with high affinity to estrogen receptor (ER) in cultured rat osteoblasts, as demonstrated in this study, represents an efficient intracrine system that allows a progesterone receptor (PR) agonist (NET) to exert potent estrogen-mediated effects in bone cells. The switch molecules that turn the osteoblasts system on, are the $5 \alpha$-steroid reductases type 1 (1) and two members of the aldo-keto reductases family, the $3 \alpha, 5 \alpha$-hydroxysteroid dehydrogenase (2) and the $3 \beta, 5 \alpha$-hydroxysteroid dehydrogenase (3). The $3 \beta, 5 \alpha$ - and $3 \alpha, 5 \alpha-N E T$ metabolites enhance osteoblasts activities involved in bone formation, whereas NET is ineffective. (Enríquez et al. 2007). 
laboratory, which have provided evidence that the tetrahydroreduced metabolites of 19-norprogestins, including NET, binds with high affinity to $\mathrm{ER} \alpha$ but not to $\operatorname{ER} \beta$, and are also capable to transactivate estrogen-dependent genes in a co-transfected HeLa cells expression system (Larrea et al. 2001, García-Becerra et al. 2002), behaving as selective ER $\alpha$ modulators with ligand-receptor structural and functional responses similar to those induced with $\mathrm{E}_{2}$ (García-Becerra et al. 2006). The number of ER binding sites in the estrogen target osteoblastic cells employed in this study was relatively low (NBS: $0 \cdot 39 \times 10^{-9} \mathrm{M}$ ), an observation similar to those previously reported in human and rat osteoblasts (Eriksen et al. 1988, Komm et al. 1988). These data are significantly different from the large number of ER binding sites documented in hormone-dependent reproductive cells and tissues (Eriksson et al. 1978, Miller \& Katzenellenbogen 1983, Chávez et al. 1985, Markaverich et al. 2001). Interestingly, the rat osteoblasts type II $E_{2}$ binding sites found in this study have been previously characterized in human osteoblast-like cells and related with bone formation (Toesca et al. 2000).

A recent study from our group (Enríquez et al. 2007) demonstrated that $3 \beta, 5 \alpha$ - and $3 \alpha, 5 \alpha$-reduced metabolites of NET induced potent estrogen-mediated stimulatory effects on neonatal, cultured rat osteoblasts. Indeed, administration of increasing concentrations of $3 \beta, 5 \alpha-\mathrm{NET}$ and $3 \alpha, 5 \alpha-\mathrm{NET}$ resulted in a significant, dose- and time-dependent response in osteoblastic cell proliferation, as determined by DNA content. In addition, NET-reduced metabolites induced a significant effect on cell differentiation as determined by alkaline phosphatase cell activity and osteocalcin and calcium osteoblasts content, as well as a significant effect on osteoblasts in mineralization, as determined by calcium deposition. Interestingly, that study showed that the effects of tetrahydro NET metabolites on osteoblasts were abolished in the presence of ICI 182 780, a potent ER antagonist, demonstrating that those effects were ER mediated.

In summary, our studies show that neonatal rat osteoblastic cells possess the capability to biotransform a potent progesterone receptor agonist (NET) to potent ER agonists $(3 \beta, 5 \alpha-\mathrm{NET}$ and $3 \alpha, 5 \alpha-\mathrm{NET})$. The complete intracrine cycle offers a plausible explanation for the effects of NET on bone formation and the beneficial effects observed in periand post-menopausal women in hormone replacement therapy, as depicted in Fig. 6.

\section{Declaration of interest}

The authors declare that there is no conflict of interest that would prejudice the impartiality of this scientific work.

\section{Funding}

Supported partially by the Division of Biological and Health Sciences, UAM and the Research Macroproject Programme (SDI.PTID-05-3), UNAM.

\section{Acknowledgements}

The expert assistance of Dr Gustavo A. García, School of Chemistry, Dr Enrique Pinzón, School of Medicine, UNAM and Dr Armando Tovar, Instituto Nacional de Ciencias Medicas y Nutrición SZ, is greatly appreciated.

\section{References}

Abdalla HI, Hart DM, Lindsay R, Leggate I \& Hooke A 1985 Prevention of bone mineral loss in postmenopausal women by norethisterone. Obstetrics and Gynecology 66 789-792.

Arzate H, Alvarez-Pérez MA, Aguilar-Mendoza ME \& Alvarez-Fregoso O 1998 Human cementum tumor cells have different features from human osteoblastic cells in vitro. Journal of Periodontal Research 33 249-258.

Bradford MM 1976 A rapid and sensitive method for the quantitation of microgram quantities of protein utilizing the principle of protein-dye binding. Analytical Biochemistry 72 248-254.

Chávez BA, Vilchis F, Pérez AE, García GA, Grillasca I \& Pérez-Palacios G 1985 Stereospecificity of the intracellular binding of norethisterone and its A-ring reduced metabolites. Journal of Steroid Biochemistry 22 121-126.

Cheng Y-C \& Prusoff WH 1973 Relationship between the inhibition constant $\left(K_{\mathrm{i}}\right)$ and the concentration of inhibitor which causes 50 per cent inhibition (I50) of an enzymatic reaction. Biochemical Pharmacology 22 3099-3108.

van der Eerden BCJ, Löwik CWGM, Wit JM \& Karperien M 2004 Expression of estrogen receptors and enzymes envolved in sex steroid metabolism in the rat tibia during sexual maturation. Journal of Endocrinology $180457-467$.

Enríquez J, Lemus AE, Chimal-Monroy J, Arzate H, García GA, Herrero B, Larrea F \& Pérez-Palacios G 2007 The effects of synthetic 19-norprogestins on osteoblastic cell function are mediated by their non-phenolic reduced metabolites. Journal of Endocrinology 193 493-504.

Eriksen EF, Colvard DS, Berg NJ, Graham ML, Mann KG, Spelsberg TC \& Riggs BL 1988 Evidence of estrogen receptors in normal human osteoblastlike cells. Science 241 84-86.

Eriksson H, Upchurch S, Hardin JW, Peck EJ \& Clark JH 1978 Heterogeneity of estrogen receptors in the cytosol and nuclear fractions of the rat uterus. Biochemical and Biophysical Research Communications 81 1-7.

García-Becerra R, Borja-Cacho E, Cooney AJ, Jackson KJ, Lemus AE, PérezPalacios G \& Larrea F 2002 The intrinsic transcriptional estrogenic activity of a non-phenolic derivative of levonorgestrel is mediated via the estrogen receptor- $\alpha$. Journal of Steroid Biochemistry and Molecular Biology 82 333-341.

García-Becerra R, Borja-Cacho E, Cooney AJ, Smith CL, Lemus AE, PérezPalacios G \& Larrea F 2006 Synthetic 19-nortestosterone derivatives as estrogen receptor alpha subtype-selective ligands induce similar receptor conformational changes and steroid receptor coactivator recruitment than natural estrogens. Journal of Steroid Biochemistry and Molecular Biology 99 108-114.

Gual C, Morato T, Hayano M, Gut M \& Dorfman RI 1962 Biosynthesis of estrogens. Endocrinology 71 920-925.

Horowitz M, Wishart JM, Need AG, Morris HA \& Nordin BEC 1993 Effects of norethisterone on bone related biochemical variables and forearm bone mineral in post-menopausal osteoporosis. Clinical Endocrinology 39 649-655.

Issa S, Schnabel D, Feix M, Wolf L, Schaefer H-E, Russell DW \& Schweikert H-U 2002 Human osteoblast-like cells express predominantly steroid $5 \alpha$ reductase type 1. Journal of Clinical Endocrinology and Metabolism 87 5401-5407.

Kaplow LS 1955 A histochemical procedure for localizing and evaluating leukocyte alkaline phosphatase activity in smears of blood and marrow. Blood 10 1023-1027.

Komm BS, Terpening CM, Benz DJ, Graeme KA, Gallegos A, Korc M, Greene GL, O'Malley BW \& Haussler MR 1988 Estrogen binding, receptor mRNA, and biologic response in osteoblast-like osteosarcoma cells. Science $24181-84$. 
Larrea F, Vilchis F, Chávez B, Pérez AE, Garza-Flores J \& Pérez-Palacios G 1987 The metabolism of 19-nor contraceptive progestins modulates their biological activity at the neuroendocrine level. Journal of Steroid Biochemistry 27 657-663.

Larrea F, García-Becerra R, Lemus AE, García GA, Pérez-Palacios G, Jackson KJ, Coleman KM, Dace R, Smith CL \& Cooney AJ 2001 A-ring reduced metabolites of 19-nor synthetic progestins as subtype selective agonists for ER $\alpha$. Endocrinology 142 3791-3799.

Lemus AE, Vilchis F, Damsky R, Chávez BA, García GA, Grillasca I \& PérezPalacios G 1992 Mechanism of action of levonorgestrel: in vitro metabolism and specific interactions with steroid receptors in target organs. Journal of Steroid Biochemistry and Molecular Biology 41 881-890.

Lemus AE, Zaga V, Santillán R, García GA, Grillasca I, Damián-Matsumura P, Jackson KJ, Cooney AJ, Larrea F \& Pérez-Palacios G 2000 The oestrogenic effects of gestodene, a potent contraceptive progestin, are mediated by its A-ring reduced metabolites. Journal of Endocrinology 165 693-702.

Lemus AE, Santillán R, Damián-Matsumura P, García GA, Grillasca I \& Pérez-Palacios G 2001 In vitro metabolism of gestodene in target organs: formation of A-ring reduced derivatives with oestrogenic activity. European Journal of Pharmacology 417 249-256.

Markaverich BM, Shoulars K \& Alejandro M 2001 Purification and characterization of nuclear type II $[3 \mathrm{H}]$ estradiol binding sites from the rat uterus: covalent labeling with [3H] luteolin. Steroids 66 707-719.

McCarthy TL, Hochberg RB, Labaree DC \& Centrella M 2007 3-Ketosteroid reductase activity and expression by fetal rat osteoblasts. Journal of Biological Chemistry 282 34003-34012.

Miller MA \& Katzenellenbogen BS 1983 Characterization and quantitation of antiestrogen binding sites in estrogen receptor-positive and -negative human breast cancer cell lines. Cancer Research 43 3094-3100.

Moralí G, Lemus AE, Oropeza MV, García GA \& Pérez-Palacios G 1990 Induction of male sexual behavior by norethisterone: role of its A-ring reduced metabolites. Pharmacology, Biochemistry, and Behavior 37 477-484.

Pérez-Palacios G, Fernandez-Aparicio MA, Medina M, Zacarias-Villarreal J \& Ulloa-Aguirre A 1981 On the mechanism of action of progestins. Acta Endocrinologica 97 320-328.
Reel JR, Humphrey RR, Shih Y-H, Windsor BL, Sakowski R, Creger PL \& Edgren RA 1979 Competitive progesterone antagonists: receptor binding and biologic activity of testosterone and 19-nortestosterone derivatives. Fertility and Sterility 31 552-561.

Riis BJ, Christiansen C, Johansen JS \& Jacobson J 1990 Is it possible to prevent bone loss in young women treated with luteinizing hormone-releasing hormone agonists? Journal of Clinical Endocrinology and Metabolism 70 920-924.

Robey PG 1995 Collagenase-treated trabecular bone fragments: a reproducible source of cells in the osteoblastic lineage. Calcified Tissue International $56 \mathrm{~S} 11-\mathrm{S} 12$

Santillán R, Pérez-Palacios G, Reyes M, Damián-Matsumura P, García GA Grillasca I \& Lemus AE 2001 Assessment of the oestrogenic activity of the contraceptive progestin levonorgestrel and its non-phenolic metabolites. European Journal of Pharmacology 427 167-174.

Scatchard G 1949 The attractions of proteins for small molecules and ions. Annals of the New York Academy of Sciences 51 660-672.

Shimodaira K, Fujikawa H, Okura F, Shimizu Y, Saito H \& Yanaihara T 1996 Osteoblast cells (MG-63 and HOS) have aromatase and $5 \alpha$-reductase activities. Biochemistry and Molecular Biology International 39 109-116.

Toesca A, Pagnotta A \& Specchia N 2000 Evidence of type II estrogen receptor in human osteoblast-like cells. Cell Biology International 24 303-309.

Vilchis F, Chávez B, Pérez AE, García GA, Angeles A \& Pérez-Palacios G 1986 Evidence that a non-aromatizable metabolite of norethisterone induces estrogen-dependent pituitary progestin receptors. Journal of Steroid Biochemistry 24 525-531.

Vittek J, Altman K, Gordon GG \& Southern AL 1974 The metabolism of $7 \alpha-3 \mathrm{H}$-testosterone by rat mandibular bone. Endocrinology 94 325-329.

Received in final form 30 October 2008

Accepted 6 November 2008

Made available online as an Accepted Preprint 10 November 2008 